\title{
Optimising the location of tsunami detection buoys and sea level monitors in the Indian Ocean
}

\begin{abstract}
In the wake of the 2004 Boxing Day tsunami disaster, a global response to implement a tsunami warning system in the Indian Ocean became imperative. Steps in this direction were initiated in 2005, with plans for the deployment of up to 24 tsunami detection buoys and the installation of sea level monitors spanning the rim of the Indian Ocean. The purpose of this paper is to investigate the optimal placement of tsunami detection buoys and sea level monitors, in order to provide warning to the greatest population potentially affected. We adopt a mathematical programming approach to examine this problem. It is determined that 10 sites (buoys and monitors) are essential in ensuring the maximum population can be warned. This has implications for construction and maintenance of the tsunami warning system in the Indian Ocean.
\end{abstract}

\section{Keywords}

Tsunami detection buoys, sea level monitors, maximal location covering problem

\section{Introduction}

On 26 December 2004 a 9.3 magnitude earthquake occurred on the sea floor near the province of Aceh, in northern Sumatra, Indonesia. It generated a tsunami with waves as high as 10.5 metres travelling at up to 8 metres per second. In two hours it reached Colombo, Sri Lanka and then the east coast of India. Almost 8 hours later, the tsunami struck fishing communities in Kenya and Somalia. No warning preceded these events and more than 240,000 lives were lost from eleven nations surrounding the Indian Ocean. 
This disaster motivated the many stakeholders involved, including the Intergovernmental Oceanographic Commission (IOC) of the United Nations Educational, Scientific and Cultural Organisation (UNESCO), to come together to begin the establishment of the Indian Ocean Tsunami Warning and Mitigation System (IOTWS). A crucial component of such a warning system is the detection/alert system. This consists of seismic detectors, sea-level monitors and deep-sea pressure sensors attached to deep ocean buoys. It is the last two of these constituents that form the focus of this study. Specifically, we investigate the optimal placement of tsunami detection buoys and sea level monitors in order to provide the greatest warning to population centres surrounding the Indian Ocean. This problem is of interest since, at the time of the writing of this paper, relatively few detection buoys were in place and a number of sea-level monitoring stations were yet to be constructed. Further, other than a paper by Braddock and Carmody (2001), little specific published scientific literature is available to assist decision-makers in determining sites for tsunami detection buoys and sea level monitors.

In the sections that follow, the optimal location problem is outlined, a model of the problem presented, the data and solution approach described, and the results presented and discussed. The paper concludes by highlighting the contributions of the research and its limitations, and suggesting future directions for research.

\section{Background to the Problem}

\subsection{Tsunami Generation}

Tsunamis are generated when a large quantity of earth is displaced or shifted underwater. This displacement may occur due to earthquake, landslide, volcanic eruption or collapse, warfare explosion or meteorite impact. Waves are formed as the water returns to 
equilibrium after displacement. The most commonly destructive tsunamis are generated by earthquakes with an epicentre along a fault in the seafloor. The Boxing Day tsunami was the result of just such an earthquake - it was associated with thrust faulting at the subduction zone between the Indian and Burma micro plates.

In the deep ocean, tsunami waves are inconspicuous, even though they travel at speeds between 500 to $1000 \mathrm{~km} / \mathrm{hr}$. It is only when they approach the shore that they become catastrophic, reaching heights of 10 metres or more. Unlike waves generated by wind which have a period of seconds, tsunami waves in the deep ocean have a period in the order of hours. The distance between tsunami wave crests can be as much as 650 kilometres with a height of only 3 centimetres, with the waves oscillating from the sea floor to the surface. A tsunami is comprised of a set of such waves the duration of which may range from several minutes to hours or even days.

\subsection{Tsunami Detection and Warning}

Before a tsunami is detected, seismic data is recorded. The $p$ wave provides information as to the depth and epicentre of an earthquake. From the measurement of this wave, the earthquake momentum magnitude $M w$ can be determined. When $M w$ is greater than 6.5, tsunami warning bulletins are issued and sea level heights are monitored. Under such circumstances, a tsunami warning station can trigger detection buoys to initiate data retrieval every 15 seconds. Alternatively, the first buoy to detect a wave with characteristics lying outside a set threshold can relay messages via satellite to a tsunami warning station.

Developed by the National Oceanic Atmospheric Administration's (NOAA) Pacific Marine Environmental Laboratory (PMEL), Deep-Ocean Assessment and Reporting of 
Tsunami (DART) buoys are engineered to measure the height of waves and the amplitude between wave crests. DART buoys comprise two components: the Bottom Pressure Recorder (BPR) and a Surface Buoy. The BPR, or tsunameter, is attached to the sea floor 1,000 to 6,000 meters below sea level and can record wave heights to within millimetre

accuracy for waves passing above with periods greater than one minute. The BPR communicates to the surface buoys using an acoustic modem, which relays the data via satellite to warning stations. The second generation of DART buoys (DART II) contains an additional modem in the surface buoy enabling two-way communication between the warning station and the BPR, allowing the BPR to be triggered into rapid data retrieval when a tsunami is suspected.

A tsunami warning system is composed of an international detection/alert system linked to national warning and disaster management centres.

\section{The Optimal Location Problem}

Despite the global significance and impact of tsunamis, there is little published literature on the problem of determining the optimal location of tsunami detection sites. Braddock and Carmody (2001) present a model for optimally locating a limited number of tsunami detection buoys in the Pacific Ocean, given 18 sample earthquake generation points, 27 coastal cities and 6 potential buoy sites. In their model they seek to give the maximum potential warning to population centres, this being measured by the number of lives that could be saved. The result was a 0-1 integer program which Braddock and Carmody (2001) solved using enumeration - when deciding to deploy just one buoy, six possible combinations result, when deploying two buoys, fifteen combinations result, and so on, yielding a total of sixty-three combinations to be examined for their 6-site problem. 
Braddock and Carmody (2001) found that, for four or more tsunami detection buoys, the warning potential did not improve, with the largest increase in warning potential being achieved through the deployment of two to three detection buoys. In fact, the highest warning potential achieved was 0.81 (on a scale of 0 to 1 ). Their model may be readily translated to the Indian Ocean.

While there is little literature on the specifics of the optimal location of tsunami detection sites, there is a rich literature on the maximal coverage location problem (MCLP), the class of location problem to which the tsunami detection problem is most closely related. The history of the MCLP can be traced from its beginnings in Church and Revelle (1974) and Church and Meadows (1979). The objective of a MCLP is to 'establish a set of $m$ facilities so as to maximize the total weight of "covered" customers [or demand points], where a customer is considered covered if she is located at most [a] certain specified distance $r$ away from the closest facility’ (Bermand and Krass 2002, p563). For the tsunami detection problem, this definition of 'covered' may be restated in terms of the timeliness of a warning being received (rather than being within a specified distance from a detection site), with the weights in the objective reflecting the population of the centre (the demand point).

A full review of the history of the MCLP cannot be undertaken here, though recent studies of the problem and its variants include, Berman and Krass (2002) and Karasakal and Karasakal (2004). Recent examinations of relevant solution approaches for the MCLP include Brotcorne et al (2002), Haouari and Chaouachi (2002), Vasko et al (2005), Gomes et al (2006), and ReVelle et al (2008), as well as Righini and Zaniboni (2007) who revisit the earlier tree search methods with their branch-and-price approach. 
These studies inform the model and solution approach found in the sections immediately following.

\section{A Model for Maximising the Effectiveness of Tsunami Detection Sites}

The model follows Braddock and Carmody (2001) and takes the form:

$$
\begin{aligned}
& \text { Maximise } E(y) \\
& \text { subject to } \sum_{w=1}^{W} y_{w} \leq X, \\
& y_{w}=\left\{\begin{array}{l}
0 \text { if site } w \text { is not occupied by a buoy or monitor } \\
1 \text { if site } w \text { is occupied by a buoy or monitor. }
\end{array} .\right.
\end{aligned}
$$

Here, the objective is to maximise the expected total warning potential, $E(y)$, a function of the deployment variables, $y_{w}$, with $\boldsymbol{y}=\left(y_{1}, y_{2}, \ldots, y_{W}\right)$ denoting the deployment vector. The warning potential reflects the proportion of the total population that can be warned by the deployment of a set of buoys and/or monitors, that is, by the detection system. Details of how the total warning potential is calculated follow in succeeding paragraphs. Deployment decisions may be constrained by the total number of buoys, $X$, available. This constraint may reflect budget restrictions or other, operational or logistical considerations.

In order to specify the expected total warning potential, it is necessary to first define a number of variables. The sites of the candidate tsunami detection buoys and monitors are denoted by $\boldsymbol{B}_{w}=$ (latitude, longitude) $)_{w}$, for $w=1, \ldots, W$, where $W$ is the total number of available detection sites. Sample points from the common tsunamigenic regions in the Indian Ocean are denoted by $\boldsymbol{G}_{u}=$ (latitude, longitude) $)_{u}$, for $u=1, \ldots, U$, where $U$ 
represents the total number of sample points chosen. Population centres are described by $\boldsymbol{P}_{v}=$ (latitude, longitude, population) $)_{v}$ for $v=1, \ldots, V$ and $p_{v}=$ population size in $\boldsymbol{P}_{v}$, where $V$ denotes the number of population centres considered. The population size at the centre is used as a proxy for the number of people that may be affected by a tsunami, as the actual population at risk depends on the size of the tsunami.

In order to determine a measure of the total expected number of people that may be warned, it is necessary to determine whether the population centres receive a timely warning - that is, a warning is received by a population centre before the tsunami reaches it. In order to determine this, three times need to be calculated: the time taken by the tsunami to travel from the generation point, $\boldsymbol{G}_{u}$, to the population centre, $\boldsymbol{P}_{v}$, the time taken by the tsunami to travel from the generation point to the detection site, $\boldsymbol{B}_{w}$, and the time taken for the detection site to communicate with the warning centre and thence the population centre. In order for a timely warning to be received, the sum of the last two times must then be less than the first.

The computation of the two tsunami travel times requires the formation of two matrices specifying the distances between the generation points and detector sites, and the generation points and population centres. The method of Great Circles is used to calculate these spherical distances given pairs of latitude and longitude values. The tsunami travel times are then computed by dividing the spherical distances by an average wave speed of $600 \mathrm{~km} / \mathrm{hr}$.

The time taken for the tsunami to travel to each population centre will be represented by $t_{u, v}$, the tsunami travel time from $\boldsymbol{G}_{u}$ to $\boldsymbol{P}_{v}$. The first component in determining the time taken for a warning to reach a population centre, is the time taken by the tsunami to reach 
the nearest detection site. The variable $t_{u}^{*}$ is used to identify the time taken for the tsunami to reach the closest detection site:

$$
t_{u}^{*}=\operatorname{Min}_{\mathrm{w}}\left(\text { tsunami travel time from } \boldsymbol{G}_{u} \text { to } \boldsymbol{B}_{w} \text { with } y_{w}=1\right. \text { ) }
$$

The population $\boldsymbol{P}_{v}$ can be warned after an elapsed time of $t_{u}^{*}+t_{d}+r_{v}$, where $t_{d}$ is the time taken to process and transmit the data to the warning station, and $r_{v}$ to be the public reaction time. Since the model is designed to determine the earliest warning time, $r_{v}$ will be set to zero, and $t_{d}$ will be set to 3 minutes (the time required for DART II buoys).

Time differences, $T_{u, v}=t^{*}{ }_{u}+t_{d}+r_{v}-t_{u, v}$, can then be found. If a tsunami approaches the population centre before the warning is issued then $t^{*}{ }_{u}+t_{d}+r_{v}>t_{u, v}$ and $T_{u, v}$ will return a positive value. The tsunami will then arrive before a warning can be sounded. A favourable situation is when the warning is given before the tsunami approaches, $t^{*}{ }_{u}+t_{d}$ $+r_{v}<t_{u, v}$ and so $T_{u, v}$ will return a negative value.

In order to define the expected total warning potential, it is necessary to determine the population at $v$ that is effectively warned of a possible tsunami when the tsunami is generated at location $u, e_{u, v}(y)$. This is a function of the deployment vector $y$ :

$$
e_{u, v}(y)=\left\{\begin{array}{cc}
0, & T_{u, v} \geq 0 \\
p_{v}, & T_{u, v}<0
\end{array} .\right.
$$

That is, if no warning is possible, the value 0 is taken, while if a population can receive a warning, the size of the population is taken. The total warning potential is then calculated by summing over all population centres, standardising over the total population of all centres (so that the quantity in the square brackets is the proportion of the total population 
warned for a given tsunami generation point), then summing over all generation points and standardizing by the total number of generation points:

$$
E(\boldsymbol{y})=\frac{1}{U} \sum_{u=1}^{U}\left[\frac{\sum_{v=1}^{V} e_{u, v}(y)}{\sum_{v=1}^{V} p_{v}}\right]
$$

The total warning potential is thus a dimensionless number bounded above by 1 and below by 0 . This then gives a measure of the effectiveness of the detection system, with values closer to 1 preferable.

\section{Data for the Model}

The data required to implement the model for the Indian Ocean includes the location and size of the population centres, the candidate locations of detection sites (buoys and sea level monitors), the average speed of tsunami waves, and the location of possible tsunamigenic events.

Representative population centres in the tsunami risk zones were selected from the Communications Plan (PTWC and JMA, 2006). However, the population data for all 91 centres were not immediately available. Accordingly, 22 centres were removed from the data set. Wikipedia (2006) and www.citypopulation.de (Brinkhoff, 2001) were used to determine the population numbers, with the location and size of the population centres included listed in Table A2 of the Appendix.

Candidate locations for buoy deployment in the Indian Ocean were determined by researchers at PMEL, in association with the United States Geological Survey (USGS). These sites are a function of the location of the geological triggers of tsunamis - 
sufficient distance from the detection buoys to the triggers is required so as not to confuse the Bottom Pressure Recorder (BPR) of the detection buoy, with seismic surface waves (Rayleigh waves). At the same time, there is a trade-off with minimising the distance to triggers to allow for earliest possible detection. Other parameters contributing to the PMEL positioning included wave amplitude, potential dispersing tsunami energy, and the probability of occurrence. Data for 24 proposed Indian Ocean locations of the tsunami detection buoys were recommended in the IOTWS Implementation Plan (IOTWS, 2007), with these listed in Table A1 of the Appendix. Candidate sea level monitoring sites can be found in the Indian Ocean Communications Plan (PTWC and JMA, 2006), with PTWC specifying sixteen candidate locations (listed in Table A4 of the Appendix).

While earthquakes are difficult to predict, their location can be estimated by examining historical earthquakes and through the location of subduction zones (Pellerin, 2005). In the Indian Ocean, the subduction zone, the Sunda Trench, is the primary region for tsunami-generating earthquakes. Closer to South Africa is the Mid Indian Ocean Ridge, or Carlsberg Ridge, where the Indian and Australian plates are moving eastward, away from the Somali and African plates. However, it is less likely that this plate separation movement is a cause of tsunamis. Initially, some 18 generation points were selected, 14 along the length of the Sunda Trench, and 4 located on the Carlsberg Ridge, with the location of the generation points given in Table A3 of the Appendix.

Mathematica (Wolfram, 2007) was then used to calculate the 1,962 distances required by the method of Great Circles using its in-built package of functions, Miscellaneous `Geodesy`. This included the distances between generation points and detection sites, and generation points and populations centres. 


\section{Solution Approach}

In solving this problem, the method of enumeration used by Braddock and Carmody (2001) is computationally intensive - instead of two matrices of size 18 by 6 and 18 by 27 solving for 63 combinations of solutions, the two matrices are of size 18 by 24 and 18 by 91 with $16,777,215\left(=2^{24}-1\right)$ combinations for the 24-site buoy problem. That is, the computational demands of the 24-site model are approximately $2^{18}$ times greater than for the six-site model. The demands increase exponentially when sea level monitors are added.

The question that therefore arises is whether to use enumeration or to use another approach. These other approaches include techniques based on branch-and-bound or branch-and-price, genetic algorithms and heuristics. While these techniques may have advantages in shorter computational time to obtain single solutions, they cannot as easily provide the kinds of information that enumeration can provide. Specifically, in solving by enumeration it is possible to not only determine optimal or near-optimal solutions, but at the same time to determine the worst case deployment and the average deployment for a given value of $X$ buoys deployed. Further, finding alternative optimal solutions requires no further effort with enumeration. It was therefore decided to use the enumeration as the solution approach. This was implemented in a conventional compiled programming language, in this case Fortran. This implementation solved the enumeration problem for the 24-site problem in approximately four minutes on a $3 \mathrm{GHz}$ Pentium system, computing the warning potential for each $X$ and reporting statistics for the minima, maxima and averages, as well as identifying those detection sites that were common to all maximal deployments. Implementation for all detection sites required the 
use of parallel programming. The results of each implementation can be found in the following section.

\section{Results}

\subsection{Buoy Sites}

Figure 1 shows the maximum, minimum and average warning potentials for $X$ varying from 1 to 24 tsunami detection buoy sites for the Indian Ocean. In Figure 1 the maximum warning potential of 0.95954970 is achieved in three of the $1,307,504$ combinations for the deployment of nine buoys. The nine sites providing this solution are $8,10,11,12,13,15,16,20$ and one of 21, 23 or 24 (see Table A1). The first eight of these buoys occur in all maximal combinations of nine or more buoys. It can be seen that the maximum warning potential does not improve if greater than 9 buoys are deployed. The maximum warning potential here is substantially higher than for Braddock and Carmody's (2001) model of the Pacific Ocean (0.81). This is to be expected due to the 18 additional candidate buoy sites.

The five buoy solution, for sites $8,12,15,16$ and 21, has a maximum warning potential of 0.95851046 which is the same, to three significant figures, as the minimum number of buoys that yield maximal warning potential. This suggests that a relatively small number of buoys are of strategic importance in determining the maximum warning potential.

Also from Figure 1, it can be seen that the average warning potential shows a relatively fast increase, with the average warning potential within 5\% of the maximum warning potential from $X=9$ onwards. This suggests that, on average, a large number of possible combinations of buoy deployment will yield an almost maximal deployment. 
The graph of the minimum warning potential demonstrates the worst case warning potential for any given $X$. For small $X$ the minimum warning potential is more than $50 \%$ worse than the maximum potential. As may be expected the minimum warning potential does increase with increasing $X$ but does not show the rapid increase seen in the average and maximum warning potentials. This demonstrates that optimal deployment is not an inconsequential matter.

Figure 1 - Warning Potential for PMEL Sites (reported to three decimal places)

\subsection{Buoy and Sea Level Monitoring Sites}

The analysis can be extended to include the deployment of sea level monitors in the tsunami warning system (in addition to the buoy sites already considered). The addition of these sites yields a total of 40 candidate sites requiring the analysis of $2^{40}-1$ combinations. Initially, this large number of sites was not examined by consideration of the forty sites simultaneously - the sixteen candidate sea level detector sites were combined with the best nine tsunami detection buoy sites $(8,10,11,12,13,15,16,20$ and 21) to enumerate the $2^{25}-1$ combinations. Figure 2 shows the outcomes of this approximation of the 40 -site problem.

Figure 2 shows that for the 25 sites, the maximum warning potential increases to 0.96556549. This is achieved in 8 of the 3,268,760 solutions for the deployment of 10 sites. The 10 sites providing this solution are buoy sites $8,10,11,16,20$, and 21 , plus sea level monitors, 3 and 12, two of buoy sites 12, 13, 15 or sea level detection sites 6, 9 or 16. The 8 key sites occur in all maximal combinations for ten and more sites 
deployed. Here then, two of the tsunami detection buoy sites are replaced by sea level detection sites in the core optimal deployment, with the potential for further substitution in the remaining two sites. This illustrates the role played by sea level monitors in tsunami warning, as previously critical buoy sites are replaced by sea level detector sites in the optimal deployment. To a small degree, this result is sensitive to the choice of tsunami generation sites. This can be clearly seen in the inclusion of sea level detection sites 3 and 6 in the optimal deployments to detect tsunamis generated in the vicinity of the Carlsberg Ridge.

Also of interest is the fact that for $X=11$ through 25 , all sites participate in at least one maximal deployment. This suggests strong substitutability of sites once the maximum total warning potential is reached.

Figure 2 - Warning Potential for 9 PMEL and 16 PTWC Sites

(reported to three decimal places)

In Figure 2 we can see a similar pattern in maximum and average warning potential as for the 24-buoy site case - the maximum warning potential is approached quickly, with the average warning potential approaching the maximum warning potential more slowly. Of interest in the minimum warning potential graph is a large jump in going from $X=9$ to 10 sites. For $X \leq 9$, it may be assumed that the lower minimums are associated with the deployment of sea level detection sites exclusively, while for $X \geq 10$, at least one buoy site must be included. This addition then lifts the graph to something closer to the minimum warning potentials found in Figure 1. 
Through the use of parallel programming it is possible to examine all 40 candidate sites through enumeration. Figure 3 shows that again the maximum warning potential is reached when 10 sites are deployed. Again, the maximum warning potential is 0.96556549. It then appears that the approach of using the best tsunami detection buoy sites with the sea level detector sites gives a good approximation to the optimal deployment for the 40 -site problem. The 10 sites yielding this warning potential include tsunami detection buoy sites 8, 10, 11 and 20, and sea level detection sites 3 and 12, as well as 4 sites chosen from, buoy sites 12 through 18, 21, 23 or 24 and sea level detection sites 6, 9 or 16 . Forty-two combinations of these 10 sites provide the maximum potential. The solution for the 40-site problem is then similar to the 25-site approximation, however, a greater number of maximal deployments exist. Interestingly, for $X$ from 10 through 39, the same set of sites can be found in all optimal deployments $-8,10,11$ and 20, and sea level detection sites 3 and 12. Further, for $X$ from 11 through 40, the superset of alternative optimal deployments contains all buoy and sea level detection sites. This suggests strong substitutability of sites in achieving maximum warning potential.

Figure 3 - Warning Potential for 24 PMEL and 16 PTWC Sites (reported to three decimal places)

\section{Conclusion}

The analysis presented in this paper supports the proposed PTWC and PMEL sites, and identifies critical sites providing the maximum warning to populations bordering the Indian Ocean. It further finds that the proposed detection system is likely to be reliable as 
only 10 sites of 40 initially proposed are required to provide maximum warning potential. Further, there is strong substitutability of sites in maximal deployments.

This study and studies of its type can provide useful information to decision-makers. In particular, information concerning the optimal deployment of detections sites, both deep ocean buoys and sea level monitoring sites, can be used in two ways. Firstly, they may be used in the planning and construction phases of a tsunami detection system, indicating which buoys and sea level monitors must be deployed. Secondly, they can be used in the maintenance phase of the detection system, suggesting which buoys and monitors are vital to the maintenance of an acceptable level of tsunami warning.

The analysis and conclusions reported here need to be qualified as they are based on the 18 tsunami generation points used. However, the 18 points used are indicative of potential tsunami generation points and selecting other generation points may have little effect on the overall results. Of more interest perhaps, is the impact of the magnitude of tsunamis on the population affected. Hence, it may be of interest to repeat the study but accommodate randomness in the impact of the tsunami. This may be undertaken along lines similar to those found in Wagner, Bhadury and Peng (2009) in their study of a stochastic location problem.

An important future extension is the application of the model to tsunami detection in the Atlantic Ocean and the Mediterranean, Caribbean and Black Seas. The imperative for this is made clear in the UNESCO Intergovernmental Oceanographic Committee estimate that "by the year 2025, three-quarters of the world's population will be living in coastal areas" (IOC, 2006), and "The expanded tsunami network that the Intergovernmental 
Oceanographic Commission of UNESCO is coordinating is just the first step in building a global tsunami warning system designed to monitor oceans and seas everywhere.” (ibid).

\section{References}

Berman O., Krass D. 2002, The generalized maximal covering location problem, Computers and Operations Research 29 563-581

Brinkhoff, T. 2001, City Population, Institut für Angewandte Photogrammetrie und Geoinformatik, viewed 11 April 2006, <http://www.citypopulation.de >

Braddock R.D., Carmody O. 2001, Optimal Location of Deep-Sea Tsunami Detectors, International Transactions in Operations Research 8 249-258

Brotcorne L., Laporte G., Semet F. 2002, Fast heuristics for large scale coveringlocation problems, Computers and Operations Research 29 651-665

Church R.L., Meadows M.E. 1979, Location modeling utilizing maximum service distance criteria, Geographical Analysis 11 358-373

Church R.L., ReVelle C. 1974, The maximal covering location problem, Papers of Regional Science Association 32 101-118

Gomes F.C., Meneses C.N., Pardolos P.M., Viana G.V.R. 2006, Experimental analysis of approximation algorithms for the vertex cover and set covering problems, Computers and Operations Research 33 3520-3534

Haouari M., Chaouachi J.S. 2002, A probabilitistic greedy search algorithm for combinatorial optimization with application to the set covering problem, Journal of the Operational Research Society 53 792-799 
Indian Ocean Tsunami Warning and Mitigation System IOTWS 2007, Implementation Plan, Third Session of the Intergovernmental Coordination Group for the Indian Ocean Tsunami Warning and Mitigation System (ICG/IOTWS-III), Bali, Indonesia, 31 July - 2 August 2006, IOC Technical Series No. 71 UNESCO

Intergovernmental Oceanographic Commission (IOC) of UNESCO 2006, From Commitments to Action: Advancements in Developing and Indian Tsunami Warning and Mitigation System

Karasakal O., Karasakal E.K. 2004, A maximal covering location model in the presence of partial coverage, Computers and Operations Research 31 1515-1526

Pacific Tsunami Warning Center and Japan Meteorological Agency 2006, Communications Plan for the Interim Tsunami Advisory Information Service for the Indian Ocean Region (ICG/IOTWS-II), 15 January 2006, Intergovernmental Oceanographic Commission (IOC) of UNESCO

Pellerin C. 2005, Pacific Ocean Buoys could be a Model for Tsunami-Monitoring System, USINFO.STATE.GOV Archive, February/10-772633

ReVelle C., Scholssberg M., Williams J. 2008, Solving the maximal covering location problem with heuristic concentration, Computer and Operations Research 35 427-435

Righini G., Zaniboni L. 2007, A branch-and-price algorithm for the multi-source Weber problem, International Journal of Operational Research 2 188-207

Vasko F.J., Knolle P.J., Spiegel D.S. 2005, An empirical study of hybrid genetic algorithms for the set covering problem, Journal of the Operational Research Society 56 $1213-1223$ 
Wagner M.R., Bhadury J., Peng S. 2009, Risk management in uncapacitated facility location models with random demands, Computers and Operations Research 36 10021011

Wikipedia Foundation Inc, Wikipedia, viewed 11 April 2006, $<$ http://en.wikipedia.org/wiki/Main_Page>

Wolfram Research Inc 2007, Mathematica Version 6.0, Champaign IL.

\section{Appendix}

Table A1 - Candidate Locations for tsunami detection buoys (PMEL)

\begin{tabular}{|l|l|l|l|l|l|}
\hline Site & Latitude & Longitude & Site & Latitude & Longitude \\
\hline 1 & $22^{\circ} \mathrm{N}$ & $63^{\circ} \mathrm{E}$ & 13 & $0^{\circ} \mathrm{N}$ & $92^{\circ} \mathrm{E}$ \\
\hline 2 & $23^{\circ} \mathrm{N}$ & $65^{\circ} \mathrm{E}$ & 14 & $3^{\circ} \mathrm{S}$ & $91^{\circ} \mathrm{E}$ \\
\hline 3 & $5^{\circ} \mathrm{N}$ & $86^{\circ} \mathrm{E}$ & 15 & $4^{\circ} \mathrm{S}$ & $95^{\circ} \mathrm{E}$ \\
\hline 4 & $9^{\circ} \mathrm{N}$ & $86^{\circ} \mathrm{E}$ & 16 & $9^{\circ} \mathrm{S}$ & $99^{\circ} \mathrm{E}$ \\
\hline 5 & $13^{\circ} \mathrm{N}$ & $86^{\circ} \mathrm{E}$ & 17 & $11^{\circ} \mathrm{S}$ & $96^{\circ} \mathrm{E}$ \\
\hline 6 & $16^{\circ} \mathrm{N}$ & $87^{\circ} \mathrm{E}$ & 18 & $12^{\circ} \mathrm{S}$ & $104^{\circ} \mathrm{E}$ \\
\hline 7 & $18^{\circ} \mathrm{N}$ & $89^{\circ} \mathrm{E}$ & 19 & $17^{\circ} \mathrm{S}$ & $106^{\circ} \mathrm{E}$ \\
\hline 8 & $15^{\circ} \mathrm{N}$ & $90^{\circ} \mathrm{E}$ & 20 & $14^{\circ} \mathrm{S}$ & $111^{\circ} \mathrm{E}$ \\
\hline 9 & $13^{\circ} \mathrm{N}$ & $89^{\circ} \mathrm{E}$ & 21 & $15^{\circ} \mathrm{S}$ & $117^{\circ} \mathrm{E}$ \\
\hline 10 & $9^{\circ} \mathrm{N}$ & $89^{\circ} \mathrm{E}$ & 22 & $18^{\circ} \mathrm{S}$ & $114^{\circ} \mathrm{E}$ \\
\hline 11 & $4^{\circ} \mathrm{N}$ & $90^{\circ} \mathrm{E}$ & 23 & $14^{\circ} \mathrm{S}$ & $121^{\circ} \mathrm{E}$ \\
\hline 12 & $1^{\circ} \mathrm{N}$ & $88^{\circ} \mathrm{E}$ & 24 & $11^{\circ} \mathrm{S}$ & $125^{\circ} \mathrm{E}$ \\
\hline
\end{tabular}

Table A2 - Population Centres

\begin{tabular}{|l|l|l|l|l|l|}
\hline Country & & $\begin{array}{l}\text { Forecast } \\
\text { Point }\end{array}$ & $\begin{array}{l}\text { Population } \\
\text { (x 10,000) }\end{array}$ & Latitude & Longitude \\
\hline Australia & 1 & Hobart & 12.605 & $43^{\circ} 16^{\prime} \mathrm{S}$ & $147^{\circ} 39^{\prime} \mathrm{E}$ \\
\hline & 2 & Kingston SE & 0.222 & $37^{\circ} \mathrm{S}$ & $139^{\circ} 24^{\prime} \mathrm{E}$ \\
\hline & 3 & Esperance & 1.400 & $34^{\circ} \mathrm{S}$ & $121^{\circ} 48^{\prime} \mathrm{E}$ \\
\hline & 4 & Augusta & 1.103 & $34^{\circ} 18^{\prime} \mathrm{S}$ & $114^{\circ} 42^{\prime} \mathrm{E}$ \\
\hline & 5 & Perth & 117.654 & $32^{\circ} \mathrm{S}$ & $115^{\circ} 18^{\prime} \mathrm{E}$ \\
\hline & 6 & Geraldtown & 2.544 & $28^{\circ} 36^{\prime} \mathrm{S}$ & $114^{\circ} 18^{\prime} \mathrm{E}$ \\
\hline & 7 & Darwin & 7.135 & $12^{\circ} 6^{\prime} \mathrm{S}$ & $130^{\circ} 42^{\prime} \mathrm{E}$ \\
\hline & 8 & Christmas Is & 0.151 & $10^{\circ} 24^{\prime} \mathrm{S}$ & $105^{\circ} 24^{\prime} \mathrm{E}$ \\
\hline
\end{tabular}




\begin{tabular}{|c|c|c|c|c|c|}
\hline & 9 & Cocos Islands & 0.062 & $12^{\circ} 6^{\prime} \mathrm{S}$ & $96^{\circ} 42^{\prime} \mathrm{E}$ \\
\hline Bangladesh & 10 & Chittagong & 14431.963 & $22^{\circ} 42^{\prime} \mathrm{N}$ & $91^{\circ} 12^{\prime} \mathrm{E}$ \\
\hline Comores & 11 & Moroni & 67.125 & $11^{\circ} 36^{\prime} \mathrm{S}$ & $43^{\circ} 18^{\prime} \mathrm{E}$ \\
\hline Reunion & 12 & St Denis & 23.660 & $20^{\circ} 48^{\prime} \mathrm{S}$ & $55^{\circ} 12^{\prime} \mathrm{E}$ \\
\hline Kerguelen Islands & 13 & Port Aux Francais & 0.015 & $49^{\circ} \mathrm{S}$ & $69^{\circ} 6^{\prime} \mathrm{E}$ \\
\hline Crozet Islands & 14 & Crozet Islands & 0.002 & $46^{\circ} 24^{\prime} \mathrm{S}$ & $51^{\circ} 48^{\prime} \mathrm{E}$ \\
\hline \multirow[t]{8}{*}{ India } & 15 & Baleshwar & 15.643 & $21^{\circ} 36^{\prime} \mathrm{N}$ & $87^{\circ} 18^{\prime} \mathrm{E}$ \\
\hline & 16 & Kakinada & 28.992 & $17^{\circ} 12^{\prime} \mathrm{N}$ & $82^{\circ} 42^{\prime} \mathrm{E}$ \\
\hline & 17 & Chennai & 6240.568 & $13^{\circ} 24^{\prime} \mathrm{N}$ & $80^{\circ} 24^{\prime} \mathrm{E}$ \\
\hline & 18 & Trivandrum & 74.500 & $8^{\circ} 18^{\prime} \mathrm{N}$ & $76^{\circ} 54^{\prime} \mathrm{E}$ \\
\hline & 19 & Mangalore & 88.286 & $13^{\circ} 18^{\prime} \mathrm{N}$ & $74^{\circ} 24^{\prime} \mathrm{E}$ \\
\hline & 20 & Bombay & 1191.440 & $18^{\circ} 48^{\prime} \mathrm{N}$ & $72^{\circ} 36^{\prime} \mathrm{E}$ \\
\hline & 21 & Port Blair & 9.998 & $11^{\circ} 54^{\prime} \mathrm{N}$ & $92^{\circ} 42^{\prime} \mathrm{E}$ \\
\hline & 22 & Great Nicobar & 4.203 & $7^{\circ} 6^{\prime} \mathrm{N}$ & $93^{\circ} 36^{\prime} \mathrm{E}$ \\
\hline \multirow[t]{8}{*}{ Indonesia } & 23 & Kupang & 20.047 & $10^{\circ} \mathrm{S}$ & $123^{\circ} 24^{\prime} \mathrm{E}$ \\
\hline & 24 & Bali & 315.116 & $8^{\circ} 42^{\prime} \mathrm{S}$ & $115^{\circ} \mathrm{E}$ \\
\hline & 25 & Cilacap & 20.693 & $7^{\circ} 48^{\prime} \mathrm{S}$ & $108^{\circ} 54^{\prime} \mathrm{E}$ \\
\hline & 26 & Bandar Lampung & 45.793 & $5^{\circ} 42^{\prime} \mathrm{S}$ & $105^{\circ} 18^{\prime} \mathrm{E}$ \\
\hline & 27 & Bengkulu & 14.640 & $3^{\circ} 54^{\prime} \mathrm{S}$ & $102^{\circ} \mathrm{E}$ \\
\hline & 28 & Padang & 71.628 & $0^{\circ} 54^{\prime} \mathrm{S}$ & $100^{\circ} 6^{\prime} \mathrm{E}$ \\
\hline & 29 & Banda Aceh & 21.554 & $5^{\circ} 30^{\prime} \mathrm{N}$ & $95^{\circ} 6^{\prime} \mathrm{E}$ \\
\hline & 30 & Belewan & 8.367 & $3^{\circ} 48^{\prime} \mathrm{S}$ & $98^{\circ} 48^{\prime} \mathrm{E}$ \\
\hline Iran & 31 & Gavater & 5.308 & $25^{\circ} \mathrm{N}$ & $61^{\circ} 18^{\prime} \mathrm{E}$ \\
\hline Kenya & 32 & Mombasa & 66.502 & $4^{\circ} \mathrm{S}$ & $39^{\circ} 42^{\prime} \mathrm{E}$ \\
\hline \multirow[t]{5}{*}{ Madagascar } & 33 & Antsiranana & 118.843 & $12^{\circ} 6^{\prime} \mathrm{S}$ & $49^{\circ} 30^{\prime} \mathrm{E}$ \\
\hline & 34 & Toamasina & 259.306 & $17^{\circ} 48^{\prime} \mathrm{S}$ & $49^{\circ} 36^{\prime} \mathrm{E}$ \\
\hline & 35 & Manakara & 3.300 & $22^{\circ} 12^{\prime} \mathrm{S}$ & $48^{\circ} 12^{\prime} \mathrm{E}$ \\
\hline & 36 & Toliara & 10.166 & $23^{\circ} 24^{\prime} \mathrm{S}$ & $43^{\circ} 36^{\prime} \mathrm{E}$ \\
\hline & 37 & Mahajanga & 13.566 & $15^{\circ} 24^{\prime} \mathrm{S}$ & $46^{\circ} 12^{\prime} \mathrm{E}$ \\
\hline \multirow[t]{2}{*}{ Malaysia } & 38 & Georgetwon & 18.057 & $5^{\circ} 24^{\prime} \mathrm{N}$ & $100^{\circ} 6^{\prime} \mathrm{E}$ \\
\hline & 39 & Port Dickson & 6.918 & $2^{\circ} 30^{\prime} \mathrm{N}$ & $101^{\circ} 42^{\prime} \mathrm{E}$ \\
\hline \multirow[t]{2}{*}{ Maldives } & 40 & Male & 9.148 & $4^{\circ} 12^{\prime} \mathrm{N}$ & $73^{\circ} 36^{\prime} \mathrm{E}$ \\
\hline & 41 & Gan & 0.250 & $0^{\circ} 36^{\prime} \mathrm{S}$ & $73^{\circ} 12^{\prime} \mathrm{E}$ \\
\hline Mauritius & 42 & Port Louis & 13.019 & $20^{\circ} \mathrm{S}$ & $57^{\circ} 18^{\prime} \mathrm{E}$ \\
\hline \multirow[t]{5}{*}{ Mozambique } & 43 & Cabo Delgado & 158.870 & $10^{\circ} 42^{\prime} \mathrm{S}$ & $40^{\circ} 42^{\prime} \mathrm{E}$ \\
\hline & 44 & Angoche & 8.899 & $15^{\circ} 30^{\prime} \mathrm{S}$ & $40^{\circ} 36^{\prime} \mathrm{E}$ \\
\hline & 45 & Quelimane & 15.319 & $18^{\circ} \mathrm{S}$ & $37^{\circ} 6^{\prime} \mathrm{E}$ \\
\hline & 46 & Beira & 41.259 & $19^{\circ} 54^{\prime} \mathrm{S}$ & $35^{\circ} 6^{\prime} \mathrm{E}$ \\
\hline & 47 & Maputo & 98.939 & $25^{\circ} 54^{\prime} \mathrm{S}$ & $32^{\circ} 48^{\prime} \mathrm{E}$ \\
\hline \multirow[t]{3}{*}{ Myanmar } & 48 & Sittwe & 10.762 & $20^{\circ} \mathrm{N}$ & $92^{\circ} 54^{\prime} \mathrm{E}$ \\
\hline & 49 & Yangon & 556.000 & $16^{\circ} 30^{\prime} \mathrm{N}$ & $96^{\circ} 24^{\prime} \mathrm{E}$ \\
\hline & 50 & Mergui & 8.860 & $12^{\circ} 48^{\prime} \mathrm{N}$ & $98^{\circ} 24^{\prime} \mathrm{E}$ \\
\hline \multirow[t]{2}{*}{ Oman } & 51 & Muscat & 63.207 & $23^{\circ} 54^{\prime} \mathrm{N}$ & $58^{\circ} 36^{\prime} \mathrm{E}$ \\
\hline & 52 & Salalah & 15.653 & $16^{\circ} 54^{\prime} \mathrm{N}$ & $54^{\circ} 6^{\prime} \mathrm{E}$ \\
\hline Pakistan & 53 & Karachi & 926.927 & $24^{\circ} 42^{\prime} \mathrm{N}$ & $66^{\circ} 54^{\prime} \mathrm{E}$ \\
\hline
\end{tabular}




\begin{tabular}{|l|l|l|l|l|l|}
\hline & 54 & Gwadar & 4.385 & $25^{\circ} 6^{\prime} \mathrm{N}$ & $62^{\circ} 24^{\prime} \mathrm{E}$ \\
\hline Seychelles & 55 & Victoria & 2.497 & $4^{\circ} 30^{\prime} \mathrm{S}$ & $55^{\circ} 36^{\prime} \mathrm{E}$ \\
\hline Singapore & 56 & Singapore & 416.370 & $1^{\circ} 12^{\prime} \mathrm{N}$ & $103^{\circ} 48^{\prime} \mathrm{E}$ \\
\hline Somalia & 57 & Mogadishu & 125.700 & $2^{\circ} \mathrm{N}$ & $45^{\circ} 30^{\prime} \mathrm{E}$ \\
\hline South Africa & 58 & Durban & 211.765 & $29^{\circ} 48^{\prime} \mathrm{S}$ & $31^{\circ} 12^{\prime} \mathrm{E}$ \\
\hline & 59 & Port Elizabeth & 74.992 & $33^{\circ} 54^{\prime} \mathrm{S}$ & $25^{\circ} 48^{\prime} \mathrm{E}$ \\
\hline & 60 & Capetown & 241.541 & $34^{\circ} 6^{\prime} \mathrm{S}$ & $18^{\circ} \mathrm{E}$ \\
\hline Sri Lanka & 61 & Jaffna & 58.900 & $9^{\circ} 54^{\prime} \mathrm{N}$ & $80^{\circ} \mathrm{E}$ \\
\hline & 62 & Trincomalee & 37.700 & $8^{\circ} 42^{\prime} \mathrm{N}$ & $81^{\circ} 18^{\prime} \mathrm{E}$ \\
\hline & 63 & Colombo & 230.500 & $6^{\circ} 54^{\prime} \mathrm{N}$ & $79^{\circ} 48^{\prime} \mathrm{E}$ \\
\hline Tanzania & 64 & Dar Es Salaam & 248.729 & $6^{\circ} 42^{\prime} \mathrm{S}$ & $39^{\circ} 24^{\prime} \mathrm{E}$ \\
\hline & 65 & Lindi & 2.815 & $9^{\circ} 48^{\prime} \mathrm{S}$ & $39^{\circ} 54^{\prime} \mathrm{E}$ \\
\hline Thailand & 66 & Phuket & 5.280 & $8^{\circ} \mathrm{N}$ & $98^{\circ} 12^{\prime} \mathrm{E}$ \\
\hline Yeman & 67 & Al Mukalla & 12.236 & $14^{\circ} 30^{\prime} \mathrm{N}$ & $49^{\circ} 12^{\prime} \mathrm{E}$ \\
\hline & 68 & Aden & 59.041 & $13^{\circ} \mathrm{N}$ & $45^{\circ} 12^{\prime} \mathrm{E}$ \\
\hline United Kingdom & 69 & Diego Garcia & 0.450 & $7^{\circ} 18^{\prime} \mathrm{S}$ & $72^{\circ} 24^{\prime} \mathrm{E}$ \\
\hline
\end{tabular}

Table A3 - Tsunami Generation Points

\begin{tabular}{|l|l|l|l|l|l|}
\hline Site & Latitude & Longitude & Site & Latitude & Longitude \\
\hline 1 & $19^{\circ} \mathrm{N}$ & $93^{\circ} \mathrm{E}$ & 10 & $7^{\circ} \mathrm{S}$ & $105^{\circ} \mathrm{E}$ \\
\hline 2 & $17^{\circ} \mathrm{N}$ & $94^{\circ} \mathrm{E}$ & 11 & $10^{\circ} \mathrm{S}$ & $110^{\circ} \mathrm{E}$ \\
\hline 3 & $15^{\circ} \mathrm{N}$ & $95^{\circ} \mathrm{E}$ & 12 & $10^{\circ} \mathrm{S}$ & $115^{\circ} \mathrm{E}$ \\
\hline 4 & $13^{\circ} \mathrm{N}$ & $92^{\circ} \mathrm{E}$ & 13 & $11^{\circ} \mathrm{S}$ & $120^{\circ} \mathrm{E}$ \\
\hline 5 & $9^{\circ} \mathrm{N}$ & $92^{\circ} \mathrm{E}$ & 14 & $9^{\circ} \mathrm{S}$ & $130^{\circ} \mathrm{E}$ \\
\hline 6 & $5^{\circ} \mathrm{N}$ & $94^{\circ} \mathrm{E}$ & 15 & $5^{\circ} \mathrm{S}$ & $75^{\circ} \mathrm{E}$ \\
\hline 7 & $3^{\circ} \mathrm{N}$ & $96^{\circ} \mathrm{E}$ & 16 & $5^{\circ} \mathrm{S}$ & $90^{\circ} \mathrm{E}$ \\
\hline 8 & $1^{\circ} \mathrm{N}$ & $98^{\circ} \mathrm{E}$ & 17 & $10^{\circ} \mathrm{S}$ & $70^{\circ} \mathrm{E}$ \\
\hline 9 & $5^{\circ} \mathrm{S}$ & $100^{\circ} \mathrm{E}$ & 18 & $10^{\circ} \mathrm{S}$ & $60^{\circ} \mathrm{E}$ \\
\hline
\end{tabular}

Table A4 - Sea Level Monitoring Stations (PTWC)

\begin{tabular}{|l|l|l|l|l|l|}
\hline Site & Latitude & Longitude & Site & Latitude & Longitude \\
\hline 1 (Cocos) & $12.1170^{\circ} \mathrm{S}$ & $98.8800^{\circ} \mathrm{E}$ & 9 (Rodrigue) & $19.6683^{\circ} \mathrm{S}$ & $63.4183^{\circ} \mathrm{E}$ \\
\hline 2 (Colombo) & $6.9500^{\circ} \mathrm{N}$ & $78.8500^{\circ} \mathrm{E}$ & 10 (Salalah) & $16.9350^{\circ} \mathrm{N}$ & $54.0067^{\circ} \mathrm{E}$ \\
\hline $3($ Gan) & $0.6867^{\circ} \mathrm{N}$ & $73.1517^{\circ} \mathrm{E}$ & 11 (Zanzibar) & $6.1500^{\circ} \mathrm{S}$ & $39.1833^{\circ} \mathrm{E}$ \\
\hline $\begin{array}{l}4 \\
\text { (Hanimaadhoo) }\end{array}$ & $6.7667^{\circ} \mathrm{N}$ & $73.1667^{\circ} \mathrm{E}$ & 12 (Sibolga) & $1.7333^{\circ} \mathrm{N}$ & $98.8000^{\circ} \mathrm{E}$ \\
\hline $5($ Lamu) & $2.2667^{\circ} \mathrm{S}$ & $40.9000^{\circ} \mathrm{E}$ & $\begin{array}{l}13 \text { (Ko Taphao } \\
\text { Noi) }\end{array}$ & $7.8167^{\circ} \mathrm{N}$ & $98.4167^{\circ} \mathrm{E}$ \\
\hline 6 (Pt La Rue) & $4.6717^{\circ} \mathrm{S}$ & $55.5283^{\circ} \mathrm{E}$ & 14 (Ko Miang) & $8.5500^{\circ} \mathrm{N}$ & $97.6333^{\circ} \mathrm{E}$ \\
\hline
\end{tabular}




\begin{tabular}{|l|l|l|l|l|l|}
\hline 7 (Male) & $4.1900^{\circ} \mathrm{N}$ & $73.5267^{\circ} \mathrm{E}$ & 15 (Padang) & $0.9500^{\circ} \mathrm{S}$ & $100.3667^{\circ} \mathrm{E}$ \\
\hline 8 (Port Luis) & $20.1550^{\circ} \mathrm{S}$ & $57.4950^{\circ} \mathrm{E}$ & 16 (Sabang) & $5.8333^{\circ} \mathrm{S}$ & $95.3333^{\circ} \mathrm{E}$ \\
\hline
\end{tabular}

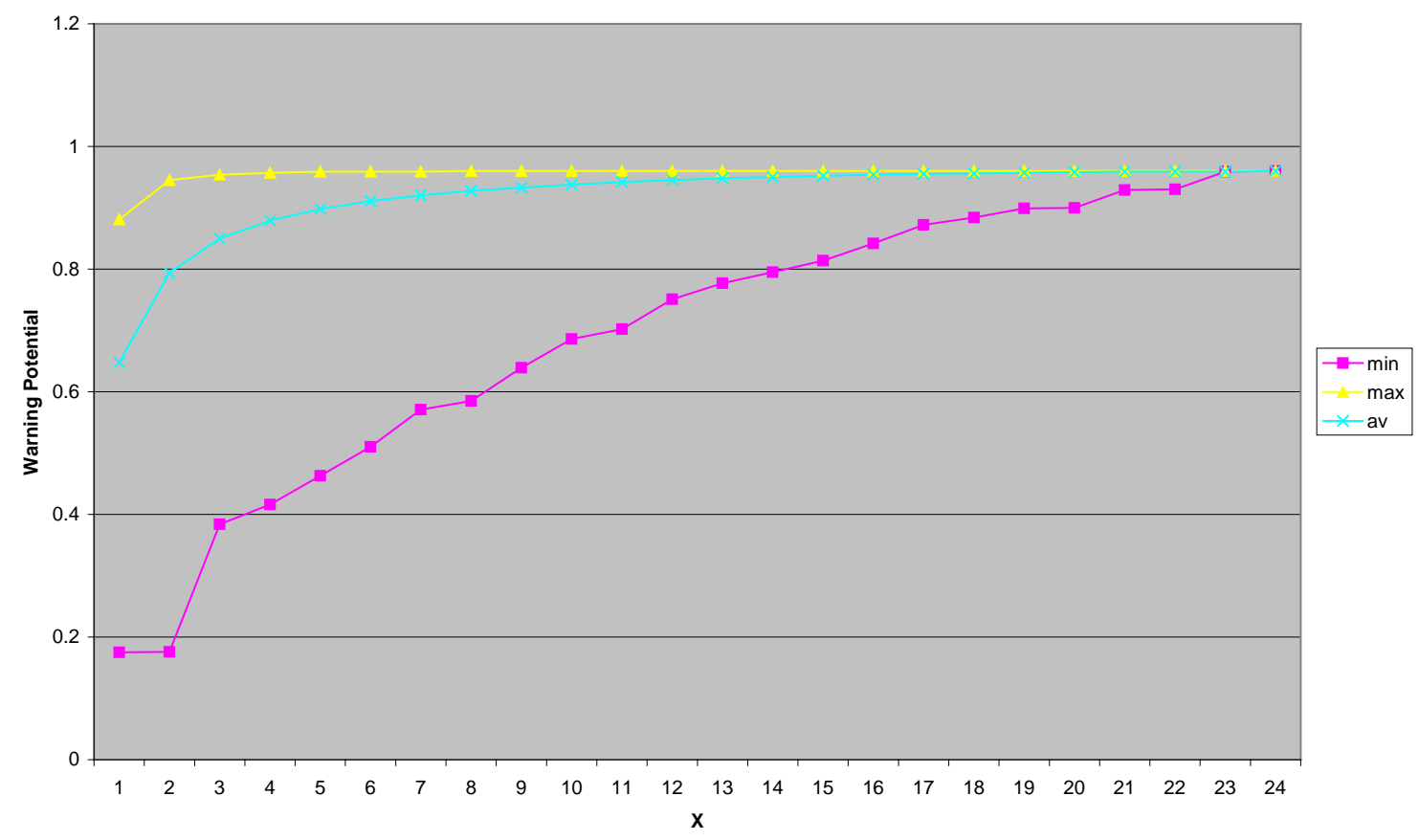

Figure 1 - Warning Potential for PMEL Sites (reported to three decimal places) 


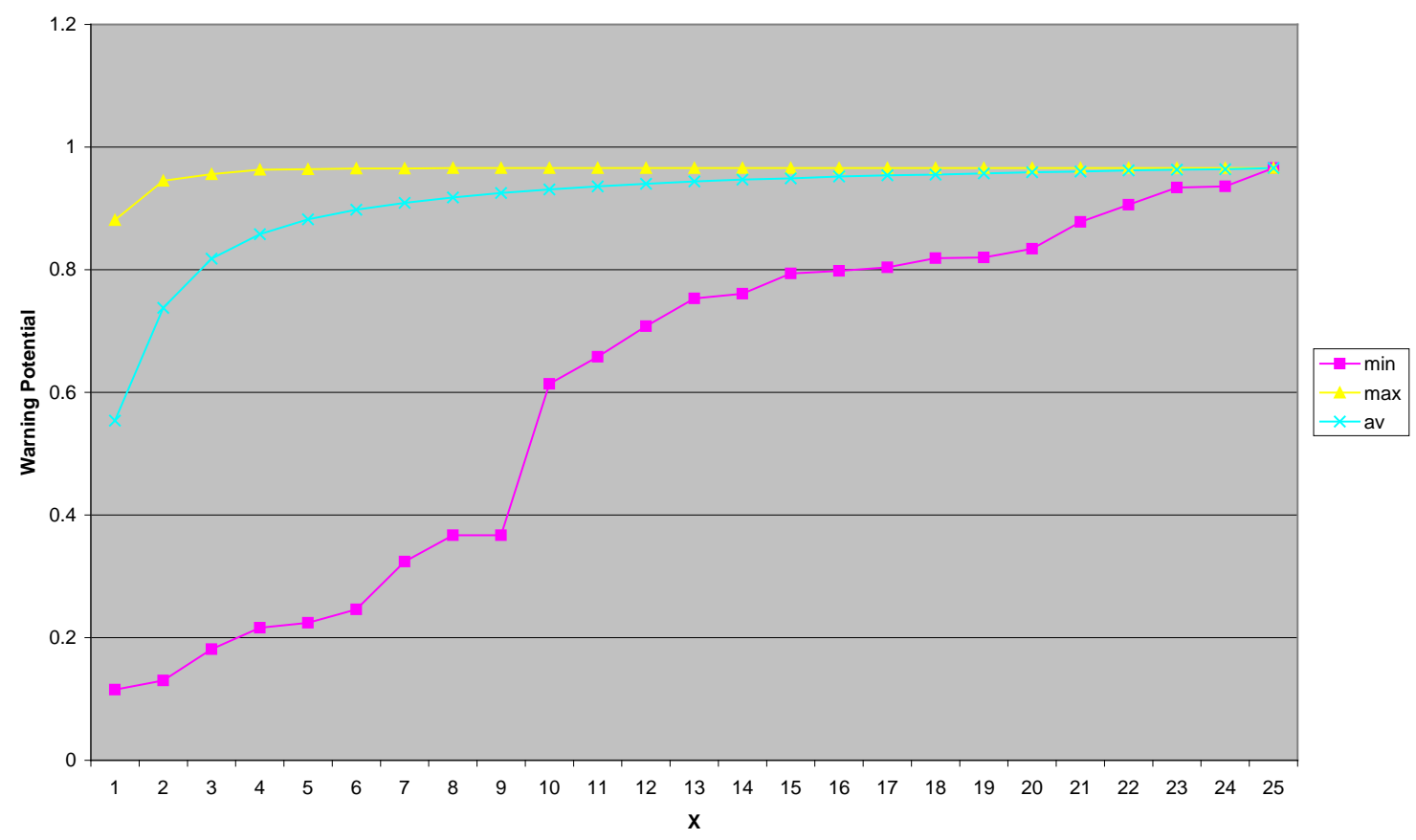

Figure 2 - Warning Potential for 9 PMEL and 16 PTWC Sites

(reported to three decimal places)

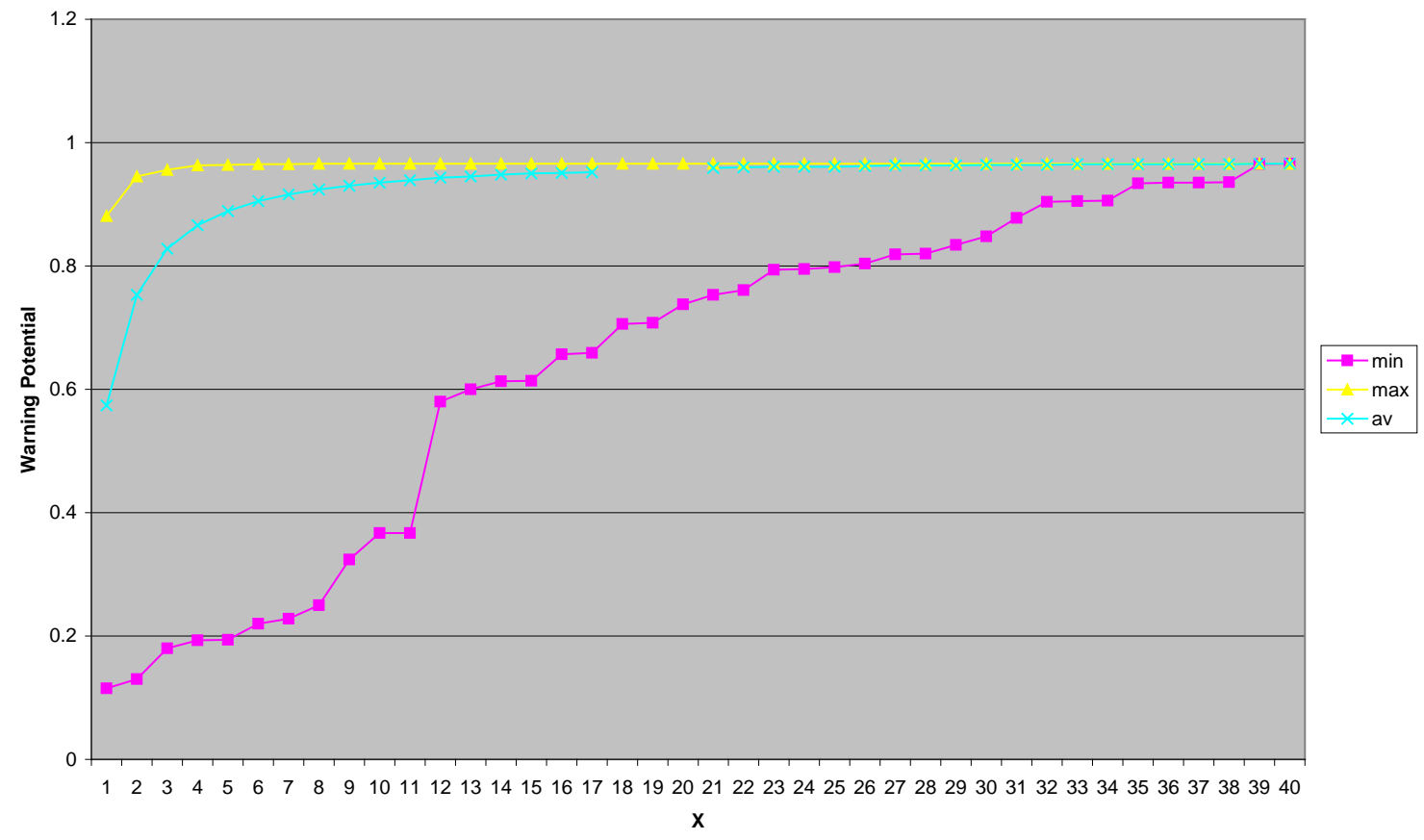

Figure 3 - Warning Potential for 24 PMEL and 16 PTWC Sites

(reported to three decimal places) 